\section{Honeyed history}

John B. Free

The Archaeology of Beekeeping.

By Eva Crane.

Duckworth/Cornell University Press:

1984. Pp.360. £25, \$39.50.

THE history of man's relationship with the bee is a long and fascinating one; throughout the ages artists and poets have expressed appreciation of the bounty of the hive and the supposed virtue and selfless toil of the bee.

On the dust cover, the publisher claims that this is the first book "to explore the rich heritage of beekeeping archaeology", This is not true. However, earlier books in English that dealt exclusively with the history of beekeeping - among them Hilda M. Ransome's classic The Sacred Bee in Ancient Times and Folklore (of which a reprint is long overdue) and two works by $\mathrm{H}$. Malcom Fraser, Beekeeping in Antiquity and History of Beekeeping in Britain - are no longer in print. During the past few years several other books have also included historical accounts of beekeeping. Nevertheless Dr Crane's book is a welcome and authoritative addition to the subject. Indeed it ranges more widely than its title implies and could more appropriately be called $A$ History of Beekeeping.

Dr Crane provides detailed information on the latest archaeological and anthropological discoveries, notable among which are rock paintings depicting bee nests and honey-hunting in Zimbabwe, South Africa, Australia and central India. These and the long-known Spanish rock paintings are considered in relation to the honey-hunting techniques, still practised by primitive peoples in many parts of the world, to rob wild honeybee colonies of their honey and brood.

From Egyptian tomb paintings, ranging from 2400 to $600 \mathrm{BC}$, we obtain our first evidence of bees being kept in hives and of the harvesting and packing of honey into pottery vessels for later consumption. Horizontal stacked hives as depicted in the paintings are still to be seen today in Arab villages. Only a few Greek pottery hives and no Roman ones have been excavated; fortunately, however, Classical writers have left us with a wealth of information on their understanding of the honeybee colony and the types of beekeeping they practised.

During the past 2,000 years there has been a proliferation of hive types and methods of beekeeping, each adapted to local conditions. Illustrations and descriptions are given of clay pots, hollow logs, and wicker and straw baskets that are still used as hives in many parts of the world, and were undoubtedly used more widely in the past. Knowledge about primitive hives and beekeeping methods is not merely of scholarly interest, as their use in modified form can be helpful in encouraging beekeeping in developing countries where there is often considerable potential for honey production. So it is crucial that we retain such information, and Dr Crane's book could be most helpful in furthering this end. For example, the evolution of hives with movable combs can be traced back to a Greek basket hive, which here deservedly receives considerable attention. The principles it embodies form the basis of a hive now used in East Africa and elsewhere.

Because most hives are of perishable material, few old ones have survived. However more durable material was used to form the shelters in which many of the early hives were placed. Some were kept in beehouses, each with its own access to the exterior; others in open-fronted shelters, and, most commonly in the United Kingdom, hives were kept individually in recesses - bee boles - in stone or brick walls. Bee boles were most common in the eighteenth and nineteenth centuries, and the author obviously finds them particularly fascinating. She devotes 46 pages to discussion of bee boles and 33 pages to other hive shelters; the International Bee Research Association's records of the bee boles and shelters in the United Kingdom are given in an 80-page Appendix. While it is useful to have this information brought together in published form, it occupies nearly half of the book and so unbalances the presentation somewhat and gives it a bias towards the United Kingdom.

The book is attractively produced, contains much interesting and well-documented information, and many unusual illustrations. It will be a most worthy and useful addition to the beekeeping sections of libraries

John B. Free is a Senior Principal Scientific Officer at Rothamsted Experimental Station, Harpenden, Hertfordshire.

\section{Hope for an answer}

\section{William H. McNeill}

\section{Weapons and Hope.}

By Freeman Dyson.

Harper \& Row: 1984. Pp.340. \$17.26, £10.95.

FREEMAN DYSON, whose last book set out to disturb the Universe, addresses this one to a more modest target: " . . . the gravest problem now facing mankind, the problem of nuclear weapons from a human rather than a technical point of view"' (p.3). A human point of view means, above all, a moral point of view. But it is the morality of Odysseus rather than of Achilles, that is, of the cunning survivor, not the dead hero.

The author wanders back and forth between personal reminiscence, literary discourse and strategic discussion in a delightful if sometimes confusing way for a reader who seeks a rigorous argument about how to escape the threat of nuclear annihilation. Perhaps Dyson chose this approach to emphasize the human dimension. More likely it was because he recognizes logical weaknesses in his recipe for escape from our dilemma, but wishes to insist that hope - persistent and unremitting hope - is the really important ingredient since only so can cheap despair, paralysis of will and atrophy of moral sense be forestalled.

Dyson wants a world without nuclear warheads. He asserts that with the appropriate exercise of moral indignation, political negotiation and technical investment in non-nuclear defensive systems the dismantling of the last nuclear device might be achieved after fifty years - with luck along the way. To reach this goal, American and Russian soldiers must be convinced that nuclear arms are counter-productive ๑) 1984 Nature Publishing Group unusable in war, and debilitating to the morale of the armed services in peace. Only cooperation between what he calls "warriors" and "victims" can lead to the abolition of nuclear arms. The problem, then, is to find a concept of national defence that does not depend on nuclear weapons, and then attract a robust political following in support of the military policies such a concept implies.

Dyson discovers this in what he calls "live and let live", the principle that "We maintain the ability to damage you as badly as you can damage us, but we prefer our own protection to your destruction" (p.274). This rationale, Dyson thinks, would allow the United States to negotiate with the Russians for mutual reduction of existing nuclear weaponry all the way down to zero - perhaps. Holding to the idea of mutually assured destruction (plus planning on first use of nuclear tactical weapons in case of a Soviet attack in Europe), he says, will permanently prevent successful negotiation for the simple reason that Russian doctrine concerning the use of nuclear weapons differs from that of the United States, being aimed at survival against strategic rocketry, if need be by means of counterforce first strike.

I have difficulty in imagining just how Dyson's concept of "live and let live" could be implemented. His most surprising suggestion pertains to how American strategic rockets should be targeted:

The answer to this question is simple: We should not aim them at all. Live and let live excludes assured destruction targeting as inconsistent with the basic principle that live Americans are to be preferred to dead Russians. Limited nuclear war and counterforce targeting are excluded because they are crisis unstable, especially since we are assuming no change in the Soviet practice of counterforce targeting. What then are we to do with our strategic weapons? We must simply maintain them as best we can, making sure that they are as invulnerable as 